\title{
Assessing the Relevance of Herbarium Collections as Tools for Conservation Biology
}

\author{
Neus Nualart ${ }^{1,3} \cdot$ Neus Ibáñez $^{1} \cdot$ Ignasi Soriano $^{2} \cdot$ Jordi López-Pujol $^{1}$ \\ ${ }^{1}$ Institut Botànic de Barcelona (IBB-CSIC-ICUB), Passeig del Migdia s/n, 08038 Barcelona, Spain \\ ${ }^{2}$ Dept. Biologia Evolutiva, Ecologia i Ciències Ambientals, Universitat de Barcelona, Diagonal 643, 08028 Barcelona, \\ Spain \\ ${ }^{3}$ Author for Correspondence; email: nnualart@ibb.csic.es
}

\begin{abstract}
Herbarium collections constitute permanent and often well-documented records of the distribution of taxa through space and time. Since their creation, their uses have dramatically expanded and with many new uses being proposed, including some for which herbaria were not initially intended for. In this paper we assess the potential of these collections on conservation biology, by providing exemplary studies that use herbarium specimens, grouped into four categories: (1) based on occurrence data, such as studies about plant extinction or introduction, or those focused on modelling their ecological niche; (2) based on the specimens themselves, such as morphological or phenological studies to evaluate the impact of climate change; (3) based in genetic data, such as phylogeographic or taxonomical studies; and (4), other applied studies.

Resumen Las colecciones de herbario constituyen un registro permanente y a menudo bien documentado de la distribución de los taxones a lo largo del espacio y el tiempo. Desde su creación, sus aplicaciones se han diversificado de forma considerable, y recientemente han emergido nuevos usos, algunos no contemplados originalmente. En este trabajo evaluamos el potencial de estas colecciones para la biología de la conservación, a partir de algunos ejemplos de estudios que usan especímenes de herbario, agrupados en cuatro categorías: (1) basados en datos de presencia, como por ejemplo estudios sobre extinciones o introducciones de plantas, o modelizaciones del nicho ecológico; (2) basados en los propios especímenes, tales como estudios morfológicos o fenológicos para evaluar el impacto del cambio climático; (3) basados en datos genéticos, como por ejemplo estudios filogeográficos o taxonómicos y (4) otros estudios aplicados.
\end{abstract}

Keywords Biological collections · Conservation · Herbarium specimens · Collections databases

\section{Introduction}

Botanical collections originated in Europe (particularly in the 15th and 16th centuries) as a consequence of the great expeditions carried out during the Renaissance, period in which plant collection was a rising fad in the continent (Meredith, 1996). Being a product of the profuse geographical discoveries of the time, from the 18th century onwards these botanical collections evolved into the ones we know today when Linnaeus decided to unbind the herbarium's volumes of his time in order to manage specimens as unique files and thus, catalogue biodiversity (Heywood, 1983). Currently, the 3000 existing herbaria worldwide preserve almost 350 million specimens (Thiers, 2016) that constitute a permanent and well documented record of plant distribution over time and space.

Although the basic methodology of collecting, pressing and handling herbarium sheets has not changed substantially over time, their use has markedly evolved. The information provided by labels, as well as the observation, measurement and sampling of specimens themselves, can be susceptible to new scientific research (Nesbitt, 2014). Consequently, botanical collections that were traditionally used as mere libraries for taxonomic and floristic purposes, presently have a much wide-ranging potential (Greve et al., 2016), including novel purposes originally not intended for (Pyke \& Ehrlich, 2010). Funk (2004) lists a total of 72 possible uses of herbarium collections, including basic research in taxonomy and systematics, but also research in ecology, history, medicine and many other biological disciplines, and even educational and informative uses. According to Lavoie (2013), the use of herbarium specimens in scientific publications has clearly increased since the first work on phytopathology in 1933. Until February 2012, this author compiled a total of 382 peer-reviewed publications with original data derived from herbaria.

Such increase in the use of herbarium materials with scientific purposes has been somewhat favoured by digitalization (Smith \& Blagoderov, 2012), especially with processes like mass digitalization, which facilitate access to partial or even full collections just a click away (for instance the Paris and Leiden herbaria; Wen et al., 2015; Seregin, 2016). Such ease in accessibility has raised questions on the utility of traditional specimens (Flannery, 2012) and even suggestions to destroy them once they have been digitalized (Clifford et al., 1990). Nonetheless, specimens continue to be indispensable as, amongst other reasons, certain morphological characters can often be hidden, be too small or even invisible in two-dimensional images (Culley, 2013). The physical elimination of herbaria would imply, on another hand, the impossibility to provide plant tissues that can be of great relevance for research, either basic or applied.

Numerous articles value the importance of herbaria in research, both dealing with the use of specimens already preserved in collections as well as stressing the need to include new field collections that can help to clarify the results of scientific studies. According to Funk et al. (2005), specimens are the base for reproducibility, an essential part of the scientific method that makes possible to repeat an experiment or confirm previous works. Furthermore, Guerin (2013) 
emphasized the low cost of such use in front of the high costs of carrying out new collections along with the value of specimens that cannot be replicated, such as those from extinct or remote populations. The need to publish articles and editorials to emphasize the value of herbaria is partly due to budget and personnel reductions that, in certain occasions, have resulted in the closing of particular collections (Dalton, 2003; Gropp, 2003) as well as the suspension of collections' research programs (Funk, 2014). Based on these developments, Funk et al. (2005) and Culley (2013) highlighted the need to cite voucher specimens in scientific articles whenever possible, bestowing the practical value given by source collections. Holland (2014) went even further, proposing that the researchers themselves give active support to herbaria, either by consultations during the preparation of research projects, contributing with costs of recollection and conservation, as well as recognizing any service provided by herbaria.

One of the most relevant yet relatively unknown herbarium applications in botanical research is in conservation biology studies (e.g., Greve et al., 2016). During recent years, various works have been done using primary data included in herbarium specimens, to acquire a better knowledge on threatened species as well as contributing on their management and recovery. The present article aims to assess the potential of these collections in different aspects of conservation biology. It is not our intention to provide an exhaustive bibliographic review but to offer examples on studies using herbarium specimens, illustrating such research with herbarium sheets considered of interest by the authors of this paper. These specimens often come from the BC herbarium (Botanical Institute of Barcelona) and the BCN herbarium (University of Barcelona). For practical reasons, examples on possible research applied to conservation using herbarium materials have been grouped into four main categories: (1) those based on occurrence data, including plant extinction and species' introduction studies, changes in latitudinal and altitudinal distribution, findings of new localities, modelling ecological niches, compilation of red lists and identification of priority conservation areas (IPAs); (2) those based on specimens' anatomical and/or life cycle traits such as morphological or phenological studies that evaluate the impact of climate change, or classical taxonomic studies; (3) those based in genetic data obtained from sampling herbarium specimens, such as studies on phylogeography, genetic diversity, and phylogeny or systematics, that further contribute to our knowledge of plants, and (4) others, including those based on the direct use of specimens (such as viability studies of seeds contained in specimens for ex situ and in situ conservation), or studies based in ethnobotanical information contained in labels.

\section{Studies on Occurrence Data}

The specimens' occurrence data is the basic information on the geographical and temporal location of a plant, i.e., the exact locality and date that it was collected. Recent specimens tend to have very precise data which allow to establish with great precision the presence of a plant in a specific place and moment, a key information for distribution maps and modelling (Merow et al., 2016). In addition, historical herbarium data, even if imprecise, are necessary to demonstrate species' extinctions, regressions or introductions, acting as testimonies of changes occurred throughout time in the flora of a given region (Ibáñez, 2006).

\section{Plant Extinctions and their Causes}

The analysis of herbarium data can provide very valuable information on extinction processes of a given species, both in relation to when and how extinction occurred (Schaffer et al., 1998). Given that many extinctions of plants are linked to the loss of natural habitats (RBG Kew, 2016), herbarium studies permit to expand our knowledge of historical changes in land use and within a diversity of habitats. Such data can be completed with the analysis of historical maps (Geri et al., 2016), information from botanical expeditions in the territory and aerial photographs (Grass et al., 2014; Baena et al., 2016).

A work on local extinctions due to changes in land use is Lienert et al. (2002), which studies the presence of Swertia perennis L. in Switzerland using herbarium sheets up to 127 years old, from 63 locations where the species has been cited. Analyses show that in 15 localities, the species can be considered extinct, and that extinctions have been more frequent at low altitudes, peripheral localities, small fens, and in fens with intensive use. According to the authors, intensification of agricultural practices and habitat fragmentation would have contributed to the local extinction of the species. Another example is the work by Aedo et al. (2015), which updates the catalogue of extinct species in Spain, analyzing from bibliographical data and herbarium materials their likely underlying causes. Anew, for 27 species catalogued, habitat loss was the main cause for extinction, although the displacement by an invasive species in one case, and overgrazing in two others, were also mentioned.

Other articles study the complete flora of an area to value the risk of species extinction. For example, Stehlik et al. (2007) evaluate local extinctions in a peri-urban region of Switzerland, on the basis of herbarium materials. Authors compare a list of 2000 specimens of 454 plants collected between 1839 and 1915 with another list of field observations from 2003 to calculate the extinction rate in relation to several variables. Results indicate that $17 \%$ to $28 \%$ of plants seem to have become extinct; such extinction rate is higher in species of wet environments, aquatic plants and annuals, those adapted to nutrient poor soils and rare species. Furthermore, as many species present in 2003 are found to have a high extinction risk, they conclude that a substantial part of the flora in the territory could disappear in the near future. 
In parallel, historical collections allow to document how the distribution of a plant has diminished over time and, at the same time, demonstrating its previous existence in places where it is currently lacking. A notable case is Stachys maritima Gouan, currently extant in only four localities of Catalonia (Iberian Peninsula), while at the beginning of the 20th century it was a relatively common species (Barriocanal \& Blanché, 2002). To illustrate this, the specimen BC-Salv903 (Portal del Mar, Barcelona, 18th century, Fig. 1) gives testimony of its presence in Barcelona's littoral, where it has disappeared completely. Since last century, this plant is in strong regression due to the transformation and destruction of beaches and coastal dunes associated with urban pressure and tourism (López-Pujol et al., 2003; Sáez et al., 2010). Another similar case is Achillea maritima (L.) Ehrend. \& Y. P. Guo, a species highly valued by herbalists, who have triggered its disappearance from many localities of the Iberian Mediterranean shoreline (Bolòs \& Vigo, 1995: 801), even though the loss of its natural habitat and of coastal dunes has also had a relevant role (Sáez et al., 2010). In the past, it was recorded in several localities from the coast of northern Catalonia as demonstrated by the sheet BC-Salv-2712 from the town of Blanes, where it is not presently found.

\section{Introduction of Alien Plants}

To obtain information in space and time on invasion patterns by non-native species, various articles have analyzed collections of alien plants from all over the world (Delisle et al., 2003; Chauvel et al., 2006; Crawford \& Hoagland, 2009). As it is well known, invasions constitute a great threat for native floras and the functioning of ecosystems (Vilà \& Ibáñez, 2011; Bellard et al., 2016); thus, their prevention and management have become crucial for natural ecosystem's conservation (González-Moreno et al., 2014).

Herbarium data can enable the identification of invasion periods by alien species in a given territory and the reconstruction of their expansion both in space and time. For instance, the study by Fuentes et al. (2008) evaluates periods of plant invasions in Chile using the data from 71,764 specimens from the CONC herbarium. According to the authors, increments in the proportion of records of alien vs. native species can be linked to the expansion in area of nonnative species in the country. Proportion curves show two significant increments, the first coinciding with the agricultural intensification in the country (1910-1940) and the second with the mechanization of wheat fields and the subsequent production increase (1980-2000).

From a conservation point of view, dating with exactitude when a species has been introduced in a country is important to monitor, in case it becomes invasive. In the study by Ibáñez et al. (2004), which uses historical sheets from the Salvador collection (BC), the introduction of new species is evaluated. For example, the first evidence in Spain for the cultivation of Pelargonium peltatum (L.) L'Hér. (BC-Salv-1489) is dated around 1705, from seeds coming from the Botanical Garden of Paris. This species is now a relatively common garden escape in the Iberian Peninsula, and even it has become naturalized in some neighbouring areas, such as the Canary Islands (Sanz et al., 2004).

Therefore, regarding currently introduced alien species, it is important to keep always voucher specimens for future studies. An example is the finding of Agave difformis A. Berger in Catalonia (Iberian Peninsula), corresponding to the first citation of the species outside its native area of Mexico (López-Pujol et al., 2016a). A specimen is preserved at the BC herbarium (BC-937141).

\section{Novelties and Altitudinal and Latitudinal Changes}

In floristic studies, the distribution area of a species is typically based on herbarium data (Applequist et al., 2007). Often, such data are also used to plan fieldtrips to revisit the localities where it has been cited (Funk, 2004) or to carry out new prospections. Occasionally, herbaria even include specimens from non-documented localities that can bring new data to improve our knowledge of plants; often, the involved specimens are still not available for the scientific community. In the article by Nualart et al. (2012) about threatened species in Catalonia (Iberian Peninsula), new altitudinal, chorological and chronological data are provided from information contained in the specimen's labels from the BC herbarium. An example is the BC-Hieraciotheca-919950 sheet of Hieracium gouanii Arv.-Touv., collected at $450 \mathrm{~m}$, an altitude considerably lower than that reported in the literature (900-1725 m).

In addition, and thanks to the data on spatial and temporal distribution of specimens, changes in the range of a given species can be evaluated, which can have, at times, important ecological and conservation implications (Feeley, 2012). Amongst other factors, such changes can respond to climate change and habitat destruction (Bergamini et al., 2009). This enables the generation of distribution maps from ancient specimens, which can be compared with those based on modern specimens (Lister \& CCRG, 2011). For instance, Wolf et al. (2016) examine changes in the distribution of species through time in different altitudinal gradients of California. As altitudinal information is sometimes missing from labels, this study uses a digital elevation model for the study area to infer such information. The authors use about 700,000 specimens belonging to more than 4000 taxa to compare mean altitudes during two periods (1895-1970 vs. 1971-2009). Results indicate that there is a significant altitudinal increase in $15 \%$ of species and, in addition, when overlapping the distribution of taxa with climatic maps, $17.9 \%$ of taxa show an increase in mean annual temperature across their niche, and $18.5 \%$ of taxa experience a similar increase in precipitation. Following such results, authors conclude that the observed altitudinal changes are mainly due to climate change.

\section{Ecological Niche Modelling}


Aiming to predict the probability of species' occurrence and habitat suitability, distribution models associate georeferenced observations of plants with multiple environmental variables (Franklin, 2013). Thanks to the ease in accessibility of herbarium records through web portals such as GBIF (Global Biodiversity Information Facility, http://www.gbif.org), these are increasingly used as inputs in distribution models (Graham et al., 2004; Enquist et al., 2009). Currently, about a milliard articles on modelling are published yearly, which means a sharp rise if compared to the dozen published yearly in the 1980s (Peterson \& Soberón, 2012). In most cases, the response of plants to climate change is evaluated by comparing the projected modelling in the current climatic scenario with those projected in future climatic scenarios that incorporate the estimated putative changes. More recently, modelling has also been applied as a complementary tool in phylogeographic studies, as making projections at the Last Glacial Maximum (LGM) represents an independent method to genetic approaches for the inference of glacial refugia and paleodistribution of plant species (e.g., Huang \& Schaal, 2012; Gavin et al., 2014). For example, López-Pujol et al. (2016b) use occurrence data for species of Centaurea subsect. Phalolepis - based mostly on specimens from the BC herbarium - to reconstruct their distribution during the LGM in Anatolia. According to the authors, modelling data supports the scenario drawn by genetic data, i.e., that the studied species would have experienced genetic exchanges thanks to the expansion of their distribution areas.

Even if the main objective of modelling studies may not be conservation per se, their results can be highly informative for decision taking, especially on issues of land management (Guisan et al., 2013). In this sense, studies on invasive plants (e.g., Giljohann et al., 2011; Tererai \& Wood, 2014; Fernández \& Hamilton, 2015; Wang et al., 2016a) allow to identify their potential areas of occupation and therefore focus on their control. On another hand, studies on rare plants (e.g., Williams et al., 2009; Marcer et al., 2013; McCune, 2016; Vroh et al., 2016; Tang et al., 2017) or threatened plants (e.g., Adhikari et al., 2012; Aguirre-Gutiérrez et al., 2015; Hassemer et al., 2016; Sántiz et al., 2016) facilitate to identify and predict the most suitable habitats for these species, determine their degree of protection linked to protected areas networks, and even to design possible reintroductions. Finally, habitat studies (e.g., Feeley, 2012; Amici et al., 2014) allow to evaluate potential distribution changes of species and to devote efforts in their mitigation.

A modelling study proposing conservation strategies in Colombian dry forests is presented by Reina-Rodríguez et al. (2016), by studying epiphytic orchids_-plants highly sensible to climate change due to their dependence on rain and water vapour to survive. Using the maximum entropy algorithm (MaxEnt) for seven species whose occurrences were obtained from herbarium materials, field observations and bibliography, their distribution was modelled in a current scenario of climate change contrasted with a future one. Results show an increase in altitude in the future scenario of climate change and thus, authors propose the establishment of altitudinal migratory corridors. Regarding distribution, the algorithm allows to identify areas of probable occurrence of species that according to authors could constitute "thermal refugia”.

\section{Red Lists and Priority Areas}

Natural history collections have also been identified as very valuable sources of information to define conservation priorities, improve decisions taken on rare and/or threatened species and apply conservation efforts with as much efficiency as possible (Krupnick et al., 2009; Kricsfalusy \& Trevisan, 2014). Even the IUCN Committee indicates their importance as a crucial step for the elaboration of red lists (IUCN, 2016). To calculate the extent of occurrence (EOO) and the area of occupation (AOO) of a given taxon, necessary to define its degree of threat, various articles point to the importance of using herbarium materials (e.g., Hernández \& Navarro, 2007; Rivers et al., 2010, 2011; Miller et al., 2012, 2013; Roberts et al., 2016). For instance, and coming back to the example of Achillea maritima, the numerous sheets deposited both in BC and BCN herbaria give testimony of its presence in several areas of the Catalan littoral until relatively recently, while it is currently absent (e.g., in the beaches around Tarragona). The existence of these specimens partly justified the compliance with the Alac criterion of IUCN (2001) to classify this species as "endangered" (EN) in the Catalan Red Book (Sáez et al., 2010).

Some authors have even created, on the basis of herbarium materials, new methods to determine the degree of threat of species that are different to those used by IUCN (2010). For instance, Kricsfalusy \& Trevisan (2014) evaluate the information from the virtual herbarium of threatened plants in Saskatchewan, Canada combined with a list of rare plants (415 species). Collected data include conservation status, distribution, habitat type, population characteristics and potential threats from the herbarium sheets of the analyzed species. These data are quantified to develop priority ratings using three criteria: rare species outside the study area, species with local rarity and species with human menaces. The use of such hierarchy, which grants greater weight to the first criterion, has resulted in a list of rare species at the provincial level that can be used as a starting point for identifying possible research needs for the conservation of the regional flora.

On the other hand, herbarium specimens can facilitate the identification of hotspots, ecoregions and centres of biodiversity, as well as the establishment of priority areas (Davy, 2005). To cite an example, Zhang et al. (2015) generate distribution maps of threatened plants in China from geographical information derived from herbarium specimens (included in the Chinese Virtual Herbarium, an online tool granting access to label data, but also to most of the scanned sheets; http://www.cvh.ac.cn/) in addition to bibliographic sources. Their objective is to explore their richness patterns and to evaluate their conservation status by overlapping species distributions with the map of provincial and national natural reserves. As an average, reserves cover only $27.5 \%$ of the areas rich in threatened species; and $12 \%$ of the 
species do not have their distribution areas protected. Thus, authors propose to designate new protected spaces in areas with high species richness (hotspots). Even, other studies evaluate priority areas with ecological niche modelling to see if these can shift in future scenarios of climate change (Wang et al., 2016b; Zhang et al., 2016).

\section{Studies with Specimens}

Herbarium materials, in addition to offer occurrence data derived from labels, allow us to observe and measure different characters of specimens collected in a given locality and date. On one side, these samples are essential in taxonomy, as morphology is the basis for the description and classification of taxa (Davis \& Heywood, 1963; Cronquist, 1978; McDade, 1995). On the other, they facilitate the evolutionary study of a plant, along with tracing changes in phenology and species morphology linked to climate change (Suarez \& Tsutsui, 2004).

\section{Classical Taxonomy}

To carry out adequate conservation programs it is necessary to know first the plants needing most protection. Even with the great current floristic knowledge, new taxa continue to be described nowadays; for instance, between 1995 and 2010 , 687 new taxa were proposed for the Ibero-Macaronesian flora (Benito, 2013), whereas for the case of China at least 2000 species await discovery (Raven, 2011). Many times, novelties are not based upon new collections; according to Bebber et al. (2010), $84 \%$ of newly published species between 1970 and 2010 in the Kew Bulletin had already been previously collected, demonstrating how herbarium specimens are a major primary source for the description of new taxa.

Amongst the many cases published over the last years, we can cite the description of Centaurea tripontina López-Alvarado, L. Sáez, Filigh., Guardiola \& Susanna (López-Alvarado et al., 2012), discovered while reviewing materials of $C$. emigrantis Bubani for the Catalan Red Book (Sáez et al., 2010). The study of one sheet (BC-145156), attributed to $C$. emigrantis, yet coming from a remote Pyrenean locality, led to the description of the new species. Another example is Erysimum polatschekii Moazzeni et al. (2016) from herbarium material in the context of a review on this genus for the Flora of Iran.

Furthermore, the distribution area of plants is a necessary information to evaluate their threat status, hence the importance of being confident on the correct identification of the specimens used to define such area. Schatz (2002) carried out a study in Madagascar to test if endemic families in the island were sufficiently known from a taxonomic point of view, as a first step to determine the threat category of the taxa contained in them. As the only available taxonomic work dated from 1963, authors reviewed primary sources of information, that is to say, herbaria. Such review brought forth the elaboration of new taxonomic keys, updating synonymy and the description of new species. The new taxonomic framework for the four families of endemic plants included 31 new species, a non-negligible $34 \%$ of the total within these families.

\section{Morphological Studies}

Changes in environmental parameters and resource availability can affect plants' growth and morphology, changes that can be evaluated thanks to specimens conserved in herbaria during centuries. According to Leger (2013) studying such changes in the size of plants can provide information to identify priorities for conservation and the most suitable candidates for conservation.

Different works study the morphological response of plants to climate change. Peñuelas \& Matamala (1990) compare, amongst other variables, stomatal density of several species collected in similar habitats but in different epochs (between 1750s and 1980s), coming from the BC and BCN herbaria. Results show a decrease in stomatal density that, according to the authors, can be attributed to the increase of $\mathrm{CO}_{2}$ in the atmosphere. In addition, Guerin et al. (2012) analyze changes in leaf morphology of Dodonaea viscosa (L.) Jacq. subsp. angustissima (DC.) J. G. West in Australia at different latitudinal gradients (linked to maximum regional temperature), using 255 herbarium sheets of up to 120 years of antiquity. Analyses on these specimens demonstrate a reduction of $2 \mathrm{~mm}$ in leaf width throughout time, equivalent to 3 degrees of latitudinal variation. They conclude that such results are consistent with morphological responses to current climate change.

Aside from climate change, variations in plant size can be attributed to other anthropogenic activities such as over-collection (Law \& Salick, 2005). For example, McGraw (2001) studied how over-collection affects Panax quinquefolius L. (the American ginseng) on the basis of 915 herbarium specimens collected throughout 186 years. A decrease was found in nine of 11 variables measured, such as root length and leaf width, confirming a general decline in plant size.

\section{Phenological Studies}

Knowing the influence of climate change in plant phenology is important to identify the most susceptible species to the temperature increase, and to adapt conservation programs accordingly to prevent its effects (Calinger et al., 2013). Changes in phenology are precisely amongst those most evident as biological responses to climate change (Parmesan \& Yohe, 2003). Consequently, the number of publications on this matter has increased exponentially since the first study by Primack et al. (2004) intended to reconstruct phenological changes through time using herbarium specimens (Lavoie, 
2013). These studies have focused on common phenological events easy to measure and with a regular observational history such as flowering, fruiting and leafing (Davis et al., 2015), mainly in relation to their onset rather than their duration, which seems to be independent of temperature (Primark et al., 2004). As comparative studies on phenologic changes using herbarium specimens and field observations indicate similar results (Robbirt et al., 2011), herbarium specimens represent a good alternative to direct data collection within natural populations, which is not always possible and has a higher cost.

Li et al. (2013) study the magnitude and tendency of the effects of climate change in flowering, examining herbarium specimens of 40 Tibetan species collected during four decades (1960-2000), with data available from the Chinese Virtual Herbarium online platform. Results show a significantly earlier flowering in time (0.5 days per year), equivalent to an advancement of 20 days during the four decades studied. Authors positively value the use of herbarium data as a significant source to analyze climate change, especially in regions where monitoring systems would be more difficult to establish. Another advantage of using herbarium specimens is that older data can be studied. For instance, Everill et al. (2014) study the leaf-out times from different deciduous trees during 174 years (1834-2008) observing an advancement in leafing of 2.06 days per 1 degree increase in local temperature. The average response for all species in all localities is an advancement of 0.4 days per decade, results that coincide with those observed with remote sensing techniques.

Also recently, a study on flowering patterns of Globularia alypum L. has been carried out in the western Mediterranean region using specimens from the BC, BCN, VAL and MPU herbaria (Clavaguera, 2012). This study has allowed to detect two phenotypes, one with late summer-autumn blossoming and the other with winter blossoming, linked to maritime and continental areas respectively. Flowering seems to be regulated in the first case by rainfall and in the second one by temperature. Variations in these parameters by the effects of climate change, thus, could imply modifications in flowering patterns of G. alypum, and the subsequent changes in ecosystem dynamics.

\section{Genetic Studies}

The possibility to extract DNA from herbarium specimens for genetic studies is known, and practiced, since the 1990s (Taylor \& Swann, 1994). Despite the degradation suffered by DNA in herbarium samples, either by the slowness in the desiccation of the specimen, the chemical products used for their conservation (Drábková, 2014), or by other reasons (e.g., nucleotide post-mortem changes; Nachman, 2013), different studies have demonstrated the success of extractions from material of different antiquity (De Castro \& Menale, 2004; Cota-Sánchez et al., 2006; Andreasen et al., 2009). This genetic information allows to carry out phylogenetic and systematic studies, as well as research on phylogeography and genetic diversity.

\section{Phylogenetic and Systematic Studies}

Phylogeny enables the study of evolutionary processes in organisms. Together with systematics, these disciplines allow for the adequate definition of taxa, augmenting thus our knowledge on them and constituting a prerequisite for the initiation of conservation and/or restoration plans. For instance, Montes-Moreno et al. (2013) analyze the taxonomic delimitation of the genus Aliella, endemic to Morocco, by means of a phylogenetic and morphological study from field and herbarium materials (with a significant part of specimens coming from the BC and BCN herbaria). Phylogenetic and morphological analyses equally indicate the convenience to include the Aliella species within the genus Phagnalon, recognizing five taxonomic entities: two as species and three as subspecies.

Such studies, however, do not only allow to delimit taxa more appropriately. Winter et al. (2013) point out that the phylogenetic diversity of a group (calculated from evolutionary relationships within phylogenetic trees) and the phylogenetic distinctiveness of a species (calculated from its relationship with other species in such trees) can be relevant for decision taking by conservationists. Phylogenetic analyses, especially if datable, give information about the age of a certain lineage and its degree of isolation, information that is very useful to establish conservation priorities. The extinction of relict, highly isolated lineages (e.g., Gingko biloba L.) could be qualified as very serious, because unique, irreplaceable evolutionary history would be lost (Mace et al., 2003; López-Pujol et al., 2011).

At present, phylogenetic studies are undergoing a revolution thanks to the methods of Next-Generation Sequencing (NGS) that allow to generate a great quantity of sequences of different genes from an organism (Harrison \& Kidner, 2011), and thus can be applied to DNA of bad quality (Bi et al., 2013). For example, Zedane et al. (2016) studied the Hesperelaea lineage, a monospecific endemic genus of the island of Guadalupe (Mexico) collected only in 1875 and considered now extinct. From DNA extraction and NGS techniques, different phylogenetic trees were obtained confirming its taxonomic position as a monospecific genus and suggesting its divergence at the beginning of the Miocene. In this study, researchers demonstrate the efficacy of the NGS technique to evaluate the taxonomic status of a lineage, which could result in the acceleration of new species' discovery from samples preserved in herbaria. Buerki \& Baker (2016) go even further, proposing to progressively include in the future the massive sampling of collections as part of the high-throughput workflow associated to the current digitalization processes, taking into consideration at the same time the preservation of specimens' integrity. According to these authors, including NGS techniques in the daily 
operation of collections would allow to obtain DNA on a large scale to develop taxonomic barcodes and potentiate, in such a way, research in the Tree of Life, information that could help in conservation policies.

\section{Phylogeographic and Genetic Diversity Studies}

Studies on phylogeography and genetic diversity use molecular markers (both nuclear and cytoplasmic) to reveal levels of diversity and genetic structure in plant populations. Based on criteria to maximize genetic diversity and/or the presence of exclusive alleles (Falk \& Holsinger, 1991; Frankham, 2010; Namoff et al., 2010), these studies are very useful in species conservation, as they allow to prioritize certain populations and protect them in situ and ex situ (either by seed or tissue conservation in germplasm banks, or by cultivation in botanical gardens). As some techniques (such as AFLP) require DNA of good quality (Devey et al., 2013) most of these studies are carried out with desiccated material directly collected in the field. Even so, there are numerous articles based on herbarium materials that undertake molecular analyses.

To illustrate this, Devey et al. (2013) study the decrease in Eligmocarpus populations-an endemic and threatened monotypic genus of Madagascar - analyzing ITS regions in herbarium materials (both from extinct and recent localities) and applying AFLP techniques to field materials. Although specimens' DNA was highly degraded, it was sequenced in some cases. The results on extinct populations show the existence of genetic connectivity between populations in the past. In addition, the current population shows a high genetic variability despite the low number of remaining individuals that, according to authors, could help in restoration programs for the species.

Moreover, genetic studies (especially phylogeographic ones) have demonstrated their value in the reconstruction of post-glacial migration routes and, at the same time, identify putative glacial refugia (Comes \& Kadereit, 1998; Hu et al., 2009). Inferring the locations of glacial refugia could be a key for the preservation of plant species; areas that acted as refugia in the past will probably act as refugia in the future (Bhagwat \& Willis, 2008; Médail \& Diadema, 2009). Beatty \& Provan (2014) investigate how plants with a disjunct distribution have persisted in two separated areas, and if these regions have acted as glacial refugia. In the case of Pinguicula grandiflora Lam., distributed in the Pyrenees and Cantabrian Mountains (Iberian Peninsula), in the Alps and in SW Ireland, these authors used some specimens from the $\mathrm{BC}$ herbarium. Phylogeographic analyses indicate that Irish populations have lesser genetic diversity than Iberian ones. Based on these results, it is concluded that the species persisted during the LGM in a southern refugium and that migration to the north was not achieved until the retreat of ice sheets.

\section{Additional Applications}

Adding to distributional, morphological, phenological and genetic data, herbarium materials can also be useful to carry out more applied studies, e.g.: (1) on over-collection of certain species, by using the additional information included in labels (e.g., ethnobotanical data); and (2) on ex situ/in situ conservation, thanks to seeds/propagules contained within specimens that can be used in germination experiments or even in recovery programs for threatened species.

\section{Studies on Species Over-Collection Linked to their Usage}

Excessive gathering of certain species, and consequently, their decline, can be evaluated from distinct specimens' attributes, such as the number of collected sheets of a species throughout time, or from the ethnobotanical information data that are sometimes recorded in the labels. Currently, one of the major challenges for ethnobotany is, thus, to detect and quantify overexploitation of natural resources to improve their conservation (Nesbitt, 2014).

An example of such studies is the work by Case et al. (2007) on over-collection of the American ginseng, Panax quinquefolius (see also Morphological Studies section), in the USA since the beginning of its commercialization at early 18th century. In this study, authors compare the number of specimens collected during 150 years with the number of specimens of four related species that are not commercialized, reporting that there has been a significant reduction in the proportion of collected specimens of $P$. quinquefolius in most of the regions analyzed. The authors conclude that this is due to a decline in the abundance of American ginseng that has lowered the chance of collecting it in the wild. On the other hand, Lulekal et al. (2012) study whether the knowledge of ethnobotanical uses of plants allows to evaluate their possible over-collection and to plan their future conservation. In this work, labels of 4717 herbarium specimens were reviewed of four plant families in Ethiopia, of which only $5.4 \%$ had documented ethnobotanical uses, representing 34.5 $\%$ of the total number of species. As the percentage of specimens with ethnobotanical information was so low, authors concluded that to know the human influence on these plants, further efforts would be needed in order to record ethnobotanical information and establish adequate conservation strategies.

Along with ethnobotanical information, specimens' labels can provide detailed indications allowing to infer how the process of overexploitation has occurred. For instance, the Achillea maritima BC-261386 specimen (Fig. 2) contains a large annotation where the collector explains that, although the species was abundant in maritime terrains in the Balearic Islands, it has been driven to quasi-extinction due to its reputation as a medicinal plant. This sheet has been included in different works dealing with the conservation of the species such as González et al. (2006) and Sáez et al. (2010). 


\section{Viability of Seeds/Propagules}

Herbaria are a highly valuable resource for seeds and propagules, which can be used for the conservation and recovery of rare or even extinct species (Bowles et al., 1993). For example, Godefroid et al. (2011) explore the possible "resurrection" [reintroduction] of 26 species extinct in Belgium, from 84 herbarium sheets between 23 and 158 years old. Results showed that only eight seeds of three specimens germinated, but surprisingly amongst the oldest ones (101-144 years). The low viability of the studied seeds is explained by their immaturity - as specimens tend to be collected in flower and not in fruit - and by the storage conditions, inadequate for seeds. On the other hand, Magrini (2011) evaluate the viability of spores of a Mediterranean threatened species (Dryopteris tyrrhena Fraser-Jenk. \& Reichst.) extracted from 10 specimens, six of which presented a successful germination. Despite the difficulties due to the small amount of spores present in specimens and their possible chemical treatment, results show the effectiveness of the method and its possible use in in situ conservation.

Conversely, it is worth mentioning that, even if seeds collected in the field are kept in germplasm banks for their optimal ex situ conservation, it is important to preserve a testimony herbarium sheet in order to facilitate the correct identification of the taxon. Both in the BC and BCN herbaria, different testimony specimens are preserved from samples of the Botanical Garden of Barcelona germplasm bank, which can also contain seeds susceptible of germinating.

\section{Discussion}

In the previous sections we have presented a selection of scientific disciplines that, while not having as a main objective the conservation and sustainable use of biodiversity, they contribute to the improvement of its knowledge and, indirectly, to an increase of the effectiveness of conservation strategies and policies. Nowadays, the continued rise in human population (from the current 7.5 billion to the projected more than 11 billion by 2100; DESA, 2015) and of anthropogenic impacts on the environment (i.e., more resource demand, climate change, etc.) largely condition the conservation and sustainable use of biodiversity. It is indispensable, thus, the application of effective measures of conservation (Rands et al., 2010), which are much more effective when a sufficient base of knowledge is available. Without doubt, basic research in taxonomy, distribution, ecology and genetics of plant species pertain to such bodies of knowledge that need to be enhanced, as stipulated in objective 19 of the 2011-2020 Strategy for the application of the Convention on Biological Diversity (CBD, 2010).

In addition, this work has intended to describe the great potential that natural history collections can have in research applied to conservation at a global scale. The cited studies herein would not have been possible without the formation and conservation during centuries of these collections (herbaria, in our case), that allow us to document the distribution and evolution of biodiversity in space and time. Collections, therefore, are not static museum pieces, but are destined to play a key role in the botany of the 21 st century (Wen et al., 2015), chiefly thanks to improved accessibility of specimens via biodiversity portals and online herbaria. Besides, during recent decades there has been an advancement of a myriad of studies that can be carried out with collection's specimens, in particular genetic research. However, many of these studies require the extraction of portions or parts of specimens, which implies finding a delicate equilibrium between the destructive extraction of samples and the preservation of collections.

Not surprisingly, research based on collections is on the rise, mainly in the use of data at large scale, such as the recent studies with about 700,000 specimens by Wolf et al. (2016) of the Californian flora, the about 900,000 specimens analyzed by Zhang et al. (2015) from the threatened flora of China and the nearly one million specimens studied by Stropp et al. (2016) from the African flora. Small scale studies should not be omitted either, as they are equally necessary for a better understanding of species, and in which specimens are the primary source of data.

Nevertheless, it must also be taken into consideration that herbarium data cannot be used indiscriminately as they can include errors, imprecisions and biases that can create false patterns and confound users (Feeley, 2012). Such problems can be grouped into: (1) errors in the identification of samples (Schatz, 2002); (2) mismatches in the distribution caused by biased effort of collectors, either by collecting in places with easy access-the "road-map effect"-, in areas close to the researchers' place of residence or work - the "botanist effect" - and in protected areas or biodiversity hotspots (Moerman \& Estabrook, 2006; Yang et al., 2013, 2014; Engemann et al., 2015); (3) gaps in spatial and temporal information (Ponder et al., 2001; Küper et al., 2006; Stropp et al., 2016); (4) imprecisions in specimens' georeferencing (Landrum \& Lafferty, 2015); and (5) overrepresentation of certain species either due to selective collection by specialists of their "target taxa" (Haripersaud, 2009) or to the predilection of collectors for the rarest and/or more attractive plants (Grass et al., 2014; Kricsfalusy \& Trevisan, 2014; Stropp et al., 2016) - and, conversely, underrepresentation of the species more difficult to collect, such as prickly plants and those a priori less interesting, e.g., alien species (Schmidt-Lebuhn et al., 2013). Bias problems, however, can be largely solved by using statistical formulas that mitigate their effect such as those proposed by Droissart et al. (2012), Feeley (2012), Grass et al. (2014) or Engemann et al. (2015). Errors and imprecisions in data can also be diminished thanks to the expertise of scientists and technicians in their processing. Sometimes, it is better not to include dubious data that could deviate the results. 
Finally, and focusing on the most common area of expertise by the authors of this paper-i.e., north-eastern Iberian Peninsula - it should be emphasized that we have been able to reference studies based on specimens from the two largest Catalan collections (mainly BC, but also BCN) for almost all disciplines included in the current compilation. This suggests that these large collections include materials diverse and extensive enough, to be used in studies of different kinds. In particular the BC herbarium, with environs 800,000 specimens, includes one of the oldest collections in the Iberian Peninsula, the Salvador collection from the 17th and 18th centuries, used in different scientific studies that have allowed us to learn more about the plants and their distribution in the past.

\section{Concluding Remarks}

In this paper, we have intended to show the potential of herbarium collections - emphasizing on herbaria of Barcelonain the improvement of biodiversity knowledge and their use in research applied to conservation. Availability of herbarium sheets and the data included in them is of great utility for biodiversity management; this is why museums and natural history centres are called to safeguard and to place value on these collections. Likewise, it would be desirable that researchers encourage investigation on these collections as they include primary data, at times unpublished and susceptible to give remarkable results in research of different types.

\section{Acknowledgements}

We thank Ugo d'Ambrosio for his translation and revision of the English text. This research was supported by project 2014SGR00514 from the Generalitat de Catalunya (Catalan Government) and by the "Proyecto Intramural Especial, PIE” (grant no. 201630I024) from the CSIC (Spanish National Research Council).

\section{References}

Adhikari, D., S. K. Barik \& K. Upadhaya. 2012. Habitat distribution modelling for reintroduction of Ilex khasiana Purk., a critically endangered tree species of northeastern India. Ecological Engineering 40: 37-43.

Aedo, C., L. Medina, P. Barberá \& M. Fernández-Albert. 2015. Extinctions of vascular plants in Spain. Nordic Journal of Botany 31: 478-488.

Aguirre-Gutiérrez, J., H. M. Serna-Chavez, A. R. Villalobos-Arambula, J. A. Pérez de la Rosa \& N. Raes. 2015. Similar but not equivalent: Ecological niche comparison across closely-related Mexican white pines. Diversity and Distributions 21: 245-257.

Amici, V., F. Geri, I. Bonini, \& D. Rocchini. 2014. Ecological niche modelling with herbarium data: A framework to improve Natura 2000 habitat monitoring. Applied Ecology and Environmental Research 12: 661-679.

Andreasen, K., M. Manktelow \& S. G. Razafimandimbison. 2009. Successful DNA amplification of a more than 200year-old herbarium specimen: Recovering genetic material from the Linnaean era. Taxon 58: 959-962.

Applequist, W. L., D. J. McGlinn, M. Miller, Q. G. Long \& J. S. Miller. 2007. How well do herbarium data predict the location of present populations? A test using Echinacea species in Missouri. Biodiversity and Conservation 16: 1397-1407.

Baena, S., D. S. Boyd, P. Smith, J. Moat \& G. M. Foody. 2016. Earth observation archives for plant conservation: 50 years monitoring of Itigi-Sumbu thicket. Remote Sensing in Ecology and Conservation 2: 95-106.

Barriocanal, C. \& C. Blanché. 2002. Estat de conservació i propostes de gestió per a Stachys maritima Gouan a la península Ibèrica. Orsis 17: 7-20.

Beatty, G. E. \& J. Provan. 2014. Phylogeographical analysis of two cold-tolerant plants with disjunct Lusitanian distributions does not support in situ survival during the last glaciation. Journal of Biogeography 41: 2185-2193.

Bebber, D. P., M. A. Carine, J. R. I. Wood, A. H. Wortley, D. J. Harris, G. T. Prance, G. Davidse, J. Paige, J. T. D. Pennington, N. K. B. Robson \& R. W. Scotland. 2010. Herbaria are a major frontier for species discovery. Proceedings of the National Academy of Sciences of the United States of America 107: 22169-22171.

Bellard, C., P. Cassey \& T. M. Blackburn. 2016. Alien species as a driver of recent extinctions. Biology Letters 12 : 20150623.

Benito, J. L. 2013. Relación aproximada de las plantas vasculares descritas para la flora ibero-macaronésica en 2010 y síntesis desde 1995. Boletín de la Asociación de Herbarios Ibero-Macaronésicos 14-15: 31-40.

Bergamini, A., S. Ungricht \& H. Hofmann. 2009. An elevational shift of cryophilous bryophytes in the last century An effect of climate warming? Diversity and Distributions 15: 871-879.

Bhagwat, S. A. \& K. J. Willis. 2008. Species persistence in northerly glacial refugia of Europe: A matter of chance or biogeographical traits? Journal of Biogeography 35: 464-482. 
Bi, K., T. Linderoth, D. Vanderpool, J. M. Good, R. Nielsen \& C. Moritz. 2013. Unlocking the vault: Nextgeneration museum population genomics. Molecular Ecology 22: 6018-6032.

Bolòs, O. \& J. Vigo. 1995. Flora dels Països Catalans, Vol. 3. Editorial Barcino, Barcelona.

Bowles, M. L., R. F. Betz \& M. M. DeMauro. 1993. Propagation of rare plants from historic seed collections: Implications for species restoration and herbarium management. Restoration Ecology 1: 101-106.

Buerki, S. \& W. J. Baker. 2016. Collections-based research in the genomic era. Biological Journal of the Linnean Society 117: 5-10.

Calinger, K. M., S. Queenborough \& P. S. Curtis. 2013. Herbarium specimens reveal the footprint of climate change on flowering trends across north-central North America. Ecology Letters 16: 1037-1044.

Case, M. A., K. M. Flinn, J. Jancaitis, A. Alley \& A. Paxton. 2007. Declining abundance of American ginseng (Panax quinquefolius L.) documented by herbarium specimens. Biological Conservation 134: 22-30.

CBD (Convention on Biological Diversity). 2010. The Strategic plan for biodiversity 2011-2020 and the Aichi biodiversity targets. Decision X/2. 18 to 29 October 2010. Nagoya.

Chauvel, B., F. Dessaint, C. Cardinal-Legrand \& F. Bretagnolle. 2006. The historical spread of Ambrosia artemisiifolia L. in France from herbarium records. Journal of Biogeography 33: 665-673.

Clavaguera, A. M. 2012. Influència del clima en la fenologia de la floració de Globularia alypum. Final Degree Project, Autonomous University of Barcelona, Bellaterra.

Clifford, H. T., R. W. Rogers \& M. E. Dettman. 1990. Where now for taxonomy? Nature 346: 602.

Comes, H. P. \& J. W. Kadereit. 1998. The effect of Quaternary climatic changes on plant distribution and evolution. Trends in Ecology and Evolution 3: 432-438.

Cota-Sánchez, J. H., K. Remarchuk \& K. Ubayasena. 2006. Ready-to-use DNA extracted with a CTAB method adapted for herbarium specimens and mucilaginous plant tissue. Plant Molecular Biology Reporter 24: 161-167.

Crawford, P. H. C. \& B. W. Hoagland. 2009. Can herbarium records be used to map alien species invasion and native species expansion over the past 100 years? Journal of Biogeography 36: 651-661.

Cronquist, A. 1978. Once again, what is a species? Pp. 3-20. In: J. A. Romberger (ed.), Biosystematics in agriculture. Allenheld, Osmun and Co., Montclair.

Culley, T. M. 2013. Why vouchers matter in botanical research. Applications in Plant Sciences 1: 1300076.

Dalton, R. 2003. Natural history collections in crisis as funding is slashed. Nature 423: 575.

Davis, P. H. \& V. H. Heywood. 1963. Principles of angiosperm taxonomy. Van Nostrand, Princeton.

Davis, C. C., C. G. Willis, B. Connolly, C. Kelly \& A. M. Ellison. 2015. Herbarium records are reliable sources of phenological change driven by climate and provide novel insights into species' phenological cueing mechanisms. American Journal of Botany 102: 1599-1609.

Davy, A. J. 2005. Museum specimens breathe life into plant conservation? Trends in Ecology and Evolution 20: 285286.

De Castro, O. \& B. Menale. 2004. PCR amplification of Michele Tenore's historical specimens and facility to utilize an alternative approach to resolve taxonomic problems. Taxon 53: 147-151.

Delisle, F., C. Lavoie, M. Jean \& D. Lachance. 2003. Reconstructing the spread of invasive plants: taking into account biases associated with herbarium specimens. Journal of Biogeography 30: 1033-1042.

DESA (United Nations, Department of Economic and Social Affairs, United Nations). 2015. World population prospects: The 2015 revision, key findings and advance tables. United Nations, New York.

Devey, D. S., F. Forest, F. Rakotonasolo, P. Ma, B. T. M. Dentinger \& S. Buerki. 2013. A snapshot of extinction in action: The decline and imminent demise of the endemic Eligmocarpus Capuron (Caesalpinioideae, Leguminosae) serves as an example of the fragility of Madagascan ecosystems. South African Journal of Botany 89: 273-280.

Drábková, L. Z. 2014. DNA extraction from herbarium specimens. Methods in Molecular Biology 1115: 69-84.

Droissart, V., O. J. Hardy, B. Sonké, F. Dahdouh-Guebas \& T. Stévart. 2012. Subsampling herbarium collections to assess geographic diversity gradients: A case study with endemic Orchidaceae and Rubiaceae in Cameroon. Biotropica 44: 44-52.

Engemann, K., B. J. Enquist, B. Sandel, B. Boyle, P. M. Jørgensen, N. Morueta-Holme, R. K. Peet, C. Violle \& J.C. Svenning. 2015. Limited sampling hampers "big data" estimation of species richness in a tropical biodiversity hotspot. Ecology and Evolution 5: 807-820.

Enquist, B. J., R. Condit, R. K. Peet, M. Schildhauer \& B. M. Thiers. 2009. The Botanical Information and Ecology Network (BIEN): Cyberinfrastructure for an integrated botanical information network to investigate the ecological impacts of global climate change on plant biodiversity. The iPlant Collaborative. Available online: http://www.iplantcollaborative.org/sites/default/files/BIEN_White_Paper.pdf (accessed Sept. 5, 2016).

Everill, P. H., R. B. Primack, E. R. Ellwood \& E. K. Melaas. 2014. Determining past leaf-out times of New England's deciduous forests from herbarium specimens. American Journal of Botany 101: 1293-1300.

Falk, D. A. \& K. E. Holsinger. 1991. Genetics and conservation of rare plants. Oxford University Press, New York.

Feeley, K. J. 2012. Distributional migrations, expansions, and contractions of tropical plant species as revealed in dated herbarium records. Global Change Biology 18: 1335-1341. 
Fernández, M. \& H. Hamilton. 2015. Ecological niche transferability using invasive species as a case study. PLoS ONE 10: e0119891.

Flannery, M. C. 2012. Flatter than a pancake: Why scanning herbarium sheets shouldn't make them disappear. Spontaneous Generations 6: 225-232.

Frankham, R. 2010. Challenges and opportunities of genetic approaches to biological conservation. Biological Conservation 143: 1919-1927.

Franklin, J. 2013. Species distribution models in conservation biogeography: Developments and challenges. Diversity and Distributions 19: 1217-1223.

Fuentes, N., E. Ugarte, I. Kühn \& S. Klotz. 2008. Alien plants in Chile: Inferring invasion periods from herbarium records. Biological Invasions 10: 649-657.

Funk, V. A. 2004. 100 Uses for a herbarium (well at least 72). Plant Science Bulletin 49: 94-95.

2014. The erosion of collections-based science: alarming trend or coincidence? The Plant Press 17: 13-14.

P. C. Hoch, L. A. Prather \& W. L. Wagner. 2005. The importance of vouchers. Taxon 54: 127-129.

Gavin, D. G., M. C. Fitzpatrick, P. F. Gugger, K. D. Heath, F. Rodríguez- Sánchez, S. Z. Dobrowski, A. Hampe, F. S. Hu, M. B. Ashcroft, P. J. Bartlein, J. L. Blois, B. C. Carstens, E. B. Davis, G. de Lafontaine, M. E. Edwards, M. Fernandez, P. D. Henne, E. M. Herring, Z. A. Holden, W. Kong, J. Liu, D. Magri, N. J. Matzke, M. S. McGlone, F. Saltré, A. L. Stigall, Y.-H. E. Tsai \& J. W. Williams. 2014. Climate refugia: joint inference from fossil records, species distribution models and phylogeography. New Phytologist 204: 37-54.

Geri, F., N. La Porta, F. Zottele \& M. Ciolli. 2016. Mapping historical data: Recovering a forgotten floristic and vegetation database for biodiversity monitoring. ISPRS International Journal of Geo-Information 5: 100.

Giljohann, K. M., C. E. Hauser, N. S. G. Williams \& J. L. Moore. 2011. Optimizing invasive species control across space: Willow invasion management in the Australian Alps. Journal of Applied Ecology 48: 1286-1294.

Godefroid, S., A. van de Vyver, P. Stoffelen, E. Robbrecht \& T. Vanderborght. 2011. Testing the viability of seeds from old herbarium specimens for conservation purposes. Taxon 60: 565-569.

González, V., R. del Hoyo \& A. Valverde. 2006. Valoració de les poblacions d'Otanthus maritimus (L.) Hoffmanns. \& Link (Compositae) al delta del Llobregat i revisió de la distribució de l'espècie a Catalunya. Butlletí de la Institució Catalana d'Història Natural 74: 29-36.

González-Moreno, P., J. M. Diez, I. Ibáñez, X. Font \& M. Vilà. 2014. Plant invasions are context-dependent: Multiscale effects of climate, human activity and habitat. Diversity and Distributions 20: 720-731.

Graham, C. H., S. Ferrier, F. Huettman, C. Moritz \& A. T. Peterson. 2004. New developments in museum-based informatics and applications in biodiversity analysis. Trends in Ecology and Evolution 19: 497-503.

Grass, A., K. Tremetsberger, R. Hössinger \& K. Bernhardt. 2014. Change of species and habitat diversity in the Pannonian region of eastern Lower Austria over 170 years: using herbarium records as a witness. Natural Resources 5: 583-596.

Greve, M., A. M. Lykke, C. W. Fagg, R. E. Gereau, G. P. Lewis, R. Marchant, A. R. Marshall, J. Ndayishimiye, J. Bogaert \& J.-C. Svenning. 2016. Realising the potential of herbarium records for conservation biology. South African Journal of Botany 105: 317-323.

Gropp, R. E. 2003. Are university natural science collections going extinct? BioScience 53: 550.

Guerin, G. R. 2013. The value of herbaria to diverse collections-based research. Australasian Systematic Botany Society Newsletter 157: 43-44.

— H. Wen \& A. J. Lowe. 2012. Leaf morphology shift linked to climate change. Biology Letters 8: 882-886.

Guisan, A., R. Tingley, J. B. Baumgartner, I. Naujokaitis-Lewis, P. R. Sutcliffe, A. I. T. Tulloch, T. J. Regan, L. Brotons, E. McDonald-Madden, C. Mantyka-Pringle, T. G. Martin, J. R. Rhodes, R. Maggini, S. A. Setterfield, J. Elith, M. W. Schwartz, B. A. Wintle, O. Broennimann, M. Austin, S. Ferrier, M. R. Kearney, H. P. Possingham \& Y. M. Buckley. 2013. Predicting species distributions for conservation decisions. Ecology Letters 16 : 1424-1435.

Haripersaud, P. P. 2009. Collecting biodiversity. PhD thesis, Utrecht University, Utrecht.

Harrison, N. \& C. A. Kidner. 2011. Next-generation sequencing and systematics: What can a billion base pairs of DNA sequence data do for you? Taxon 60: 1552-1566.

Hassemer, G., R. De Giovanni \& R. Trevisan. 2016. The use of potential distribution models in the study of the distribution and conservation status of plants: The case of Plantago L. (Plantaginaceae) in Brazil. The Journal of the Torrey Botanical Society 143: 38-49.

Hernández, H. M. \& M. Navarro. 2007. A new method to estimate areas of occupancy using herbarium data. Biodiversity and Conservation 16: 2457-2470.

Heywood, V. H. 1983. The mythology of taxonomy. Transactions of the Botanical Society of Edinburgh 44: 79-94.

Holland, A. 2014. How will the changing uses of herbarium collections affect their future? Australasian Systematic Botany Society Newsletter 160: 5-7.

Hu, F. S., A. Hampe \& R. J. Petit. 2009. Paleoecology meets genetics: deciphering past vegetational dynamics. Frontiers in Ecology and the Environment 7: 371-379. 
Huang, P. \& B. A. Schaal. 2012. Association between the geographic distribution during the last glacial maximum of Asian wild rice, Oryza rufipogon (Poaceae), and its current genetic variation. American Journal of Botany 99: 18661874.

Ibáñez, N. 2006. Estudis sobre cinc herbaris històrics de l'Institut Botànic de Barcelona. PhD thesis, University of Barcelona, Barcelona.

, I. Soriano \& J. M. Montserrat. 2004. Cultivated plants in the Salvador Herbarium (17-18th century). 2nd World Botanic Gardens Congress. Barcelona, 17-22 April 2004.

IUCN (International Union for Conservation of Nature). 2001. IUCN Red List Categories and Criteria: Version 3.1. IUCN Species Survival Commission, Gland and Cambridge.

- 2010. Guidelines for application of the IUCN Red List criteria at regional levels: Version 4.0. IUCN Species Survival Comission. Available online: http://s3.amazonaws.com/iucnredlistnewcms/staging/public/attachments/3154/reg_guidelines_en.pdf (accessed Sept. 7, 2016).

- 2016. Guidelines for using the IUCN Red List categories and criteria. Version 12. Prepared by the Standards and Petitions Subcommittee. Available online: http://www.iucnredlist.org/documents/RedListGuidelines.pdf (accessed Sept. 7, 2016).

Kricsfalusy, V. V. \& N. Trevisan. 2014. Prioritizing regionally rare plant species for conservation using herbarium data. Biodiversity and Conservation 23: 39-61.

Krupnick, G. A., W. J. Kress \& W. L. Wagner. 2009. Achieving target 2 of the Global Strategy for Plant Conservation: building a preliminary assessment of vascular plant species using data from herbarium specimens. Biodiversity and Conservation 18: 1459-1474.

Küper, W., J. H. Sommer, J. C. Lovett \& W. Barthlott. 2006. Deficiency in African plant distribution data - Missing pieces of the puzzle. Botanical Journal of the Linnean Society 150: 355-368.

Landrum, L. R. \& D. Lafferty. 2015. PROXIMITY and CORRELATION: Two new computer programs for mining phytosociological information held in herbarium databases using central Arizona as a test case. Taxon 64: 998-1016.

Lavoie, C. 2013. Biological collections in an ever changing world: Herbaria as tools for biogeographical and environmental studies. Perspectives in Plant Ecology, Evolution and Systematics 15: 68-76.

Law, W. \& J. Salick. 2005. Human-induced dwarfing of Himalayan snow lotus, Saussurea laniceps (Asteraceae). Proceedings of the National Academy of Sciences of the United States of America 102: 10218-10220.

Leger, E. A. 2013. Annual plants change in size over a century of observations. Global Change Biology 19: $2229-2239$.

Li, Z., N. Wu, X. Gao, Y. Wu \& K. P. Oli. 2013. Species-level phenological responses to 'global warming' as evidenced by herbarium collections in the Tibetan Autonomous Region. Biodiversity and Conservation 22: 141-152.

Lienert, J., M. Fischer \& M. Diemer. 2002. Local extinctions of the wetland specialist Swertia perennis L. (Gentianaceae) in Switzerland: A revisitation study based on herbarium records. Biological Conservation 103: 65-76.

Lister, A. M. \& CCRG (Climate Change Research Group). 2011. Natural history collections as sources of long-term datasets. Trends in Ecology and Evolution 26: 153-154.

López-Alvarado, J., L. Sáez, R. Filigheddu, M. Guardiola \& A. Susanna. 2012. Centaurea tripontina (Compositae), a new species from the Pre-Pyrenean mountains, Spain. Plant Biosystems 146: 273-275.

López-Pujol, J., D. Guillot, P. Nájera, N. Nualart \& P. Van der Meer. 2016a. Primera cita del endemismo mexicano Agave difformis A. Berger (Agavaceae) fuera de su área de distribución nativa. Acta Botanica Mexicana 115: 9-25.

— , S. López-Vinyallonga, A. Susanna, K. Ertuğrul, T. Uysal, O. Tugay, A. Guetat \& N. Garcia-Jacas. $2016 b$. Speciation and genetic diversity in Centaurea subsect. Phalolepis in Anatolia. Scientific Reports 6: $37818 .$.

$\longrightarrow$, R. Orellana, M. Bosch, J. Simon \& C. Blanché. 2003. Effects of habitat fragmentation on allozyme diversity and conservation status of the coastal sand dunes plant Stachys maritima (Lamiaceae) in the Iberian Peninsula. Plant Biology 5: 504-512.

— , F.-M. Zhang, H.-Q. Sun, T.-S. Ying \& S. Ge. 2011. Mountains of Southern China as "plant museums" and "plant cradles": Evolutionary and conservation insights. Mountain Research and Development 31: 261-269.

Lulekal, E., Z. Asfaw, E. Kelbessa \& P. Van Damme. 2012. Linking ethnobotany, herbaria and flora to conservation: the case of four Angiosperm families at the National Herbarium of Ethiopia. Journal of East African Natural History 101: 99-125.

Mace, G. M., J. L. Gittleman \& A. Purvis. 2003. Preserving the tree of life. Science 300: 1707-1709.

Magrini, S. 2011. Herbaria as useful spore banks for integrated conservation strategies of pteridophytic diversity. Plant Biosystems 145: 635-637.

Marcer, A., L. Sáez, R. Molowny-Horas, X. Pons \& J. Pino. 2013. Using species distribution modelling to disentangle realised versus potential distributions for rare species conservation. Biological Conservation 166: 221-230.

McCune, J. L. 2016. Species distribution models predict rare species occurrences despite significant effects of landscape context. Journal of Applied Ecology 53: 1871-1879..

McDade, L. A. 1995. Species concepts and problems in practice: Insight from botanical monographs. Systematic Botany 20: 606-622.

McGraw, J. B. 2001. Evidence for decline in stature of American ginseng plants from herbarium specimens. Biological Conservation 98: 25-32. 
Médail, F. \& K. Diadema. 2009. Glacial refugia influence plant diversity patterns in the Mediterranean Basin. Journal of Biogeography 36: 1333-1345.

Meredith, A. L. 1996. Roles of natural history collections. Annals of the Missouri Botanical Garden 83: 536-545.

Merow, C., J. M. Allen, M. E. Aiello-Lammens \& J. A. Silander Jr. 2016. Improving niche and range estimates with Maxent and point process models by integrating spatially explicit information. Global Ecology and Biogeography 25: $1022-1036$.

Miller, J. S., G. A. Krupnick, H. Stevens, H. Porter-Morgan, B. Boom, P. Acevedo-Rodríguez, J. Ackerman, D. Kolterman, E. Santiago, C. Torres \& J. Velez. 2013. Toward Target 2 of the Global Strategy for Plant Conservation: An expert analysis of the Puerto Rican flora to validate new streamlined methods for assessing conservation status. Annals of the Missouri Botanical Garden 99: 199-205.

- H. A. Porter-Morgan, H. Stevens, B. Boom, G. A. Krupnick, P. Acevedo-Rodríguez, J. Fleming \& M. Gensler. 2012. Addressing target two of the Global Strategy for Plant Conservation by rapidly identifying plants at risk. Biodiversity \& Conservation 21: 1877-1887.

Moazzeni, H., M. Assadi, G. Zare, M. Mirtadzadini \& I. A. Al-Shehbaz. 2016. Taxonomic novelties in Erysimum for the Flora of Iran: E. polatschekii, a new alpine endemic, and E. scabrum, a new record. Phytotaxa 269: 47-53.

Moerman, D. E. \& G. F. Estabrook. 2006. The botanist effect: counties with maximal species richness tend to be home to universities and botanists. Journal of Biogeography 33: 1969-1974.

Montes-Moreno, N., N. Garcia-Jacas, C. Benedí \& L. Sáez. 2013. Evaluation of the taxonomic status of the genus Aliella (Compositae, Gnaphalieae): a recircumscription of the genus Phagnalon. Phytotaxa 148: 1-31.

Nachman, M. W. 2013. Genomics and museum specimens. Molecular Ecology 22: 5966-5968.

Namoff, S., C. E. Husby, J. Francisco-Ortega, L. R. Noblick, C. E. Lewis \& M. P. Griffith. 2010. How well does a botanical garden collection of a rare palm capture the genetic variation in a wild population? Biological Conservation 143: 1110-1117.

Nesbitt, M. 2014. Use of herbarium specimens in ethnobotany. Pp. 313-328. In: Salick, J., K. Konchar \& M. Nesbitt (eds.), Curating biocultural collections: a handbook. Royal Botanic Gardens, Kew.

Nualart, N., N. Montes-Moreno, L. Gavioli \& N. Ibáñez. 2012. L’herbari de l'Institut Botànic de Barcelona com una eina per la conservació dels tàxons endèmics i amenaçats de Catalunya. Collectanea Botanica 31: 81-101.

Parmesan, C. \& G. Yohe. 2003. A globally coherent fingerprint of climate change impacts across natural systems. Nature 421: 37-42.

Peñuelas, J. \& R. Matamala. 1990. Changes in N and S leaf content, stomatal density and specific leaf area of 14 plant species during the last three centuries of $\mathrm{CO}_{2}$ increase. Journal of Experimental Botany 41: 1119-1124.

Peterson, A. T. \& J. Soberón. 2012. Integrating fundamental concepts of ecology, biogeography, and sampling into effective ecological niche modeling and species distribution modeling. Plant Biosystems 146: 789-796.

Ponder, W. F., G. A. Carter, P. Flemons \& R. R. Chapman. 2001. Evaluation of museum collection data for use in biodiversity assessment. Conservation Biology 15: 648-657.

Primack, D., C. Imbres, R. B. Primack, A. J. Miller-Rushing \& P. Del Tredici. 2004. Herbarium specimens demonstrate earlier flowering times in response to warming in Boston. American Journal of Botany 91: 1260-1264.

Pyke, G. H. \& P. R. Ehrlich. 2010. Biological collections and ecological/environmental research: A review, some observations and a look to the future. Biological Reviews 85: 247-266.

Rands, M. R. W., W. M. Adams, L. Bennun, S. H. M. Butchart, A. Clements, D. Coomes, A. Entwistle, I. Hodge, V. Kapos, J. P. W. Scharlemann, W. J. Sutherland \& B. Vira. 2010. Biodiversity conservation: challenges beyond 2010. Science 329: 1298-1303.

Raven, P. H. 2011. Plant conservation in the future: new challenges, new opportunities. Plant Diversity and Resources 33: 1-9.

RBG Kew (Royal Botanic Gardens, Kew). 2016. The state of the world's plants report - 2016. Royal Botanic Gardens, Kew.

Reina-Rodríguez, G. A., J. E. Rubiano, F. A. Castro Llanos \& J. T. Otero. 2016. Spatial distribution of dry forest orchids in the Cauca River Valley and Dagua Canyon: Towards a conservation strategy to climate change. Journal for Nature Conservation 30: 32-43.

Rivers, M. C., S. P. Bachman, T. R. Meagher, E. N. Lughadha \& N. A. Brummitt. 2010. Subpopulations, locations and fragmentation: Applying IUCN red list criteria to herbarium specimen data. Biodiversity and Conservation 19: 2071-2085.

— L. Taylor, N. A. Brummitt, T. R. Meagher, D. L. Roberts \& E. N. Lughadha. 2011. How many herbarium specimens are needed to detect threatened species? Biological Conservation 144: 2541-2547.

Robbirt, K. M., A. J. Davy, M. J. Hutchings \& D. L. Roberts. 2011. Validation of biological collections as a source of phenological data for use in climate change studies: A case study with the orchid Ophrys sphegodes. Journal of Ecology 99: 235-241.

Roberts, D. L., L. Taylor \& L. N. Joppa. 2016. Threatened or Data Deficient: assessing the conservation status of poorly known species. Diversity and Distributions 22: 558-565. 
Sáez, L., P. Aymerich \& C. Blanché. 2010. Llibre vermell de les plantes vasculars endèmiques i amenaçades de Catalunya. Argania Editio, Barcelona.

Sántiz, E., C. Lorenzo, A. Carrillo-Reyes, D. Navarrete \& G. Islebe. 2016. Effect of climate change on the distribution of a critically threatened species. Therya 7: 147-159.

Sanz, M., E. D. Dana \& E. Sobrino. 2004. Atlas de las plantas alóctonas invasoras en España. Dirección General para la Biodiversidad, Ministerio de Medio Ambiente. Madrid.

Schaffer, H. B., R. N. Fisher \& C. Davidson. 1998. The role of natural history collections in documenting species declines. Trends in Ecology and Evolution 13: 27-30.

Schatz, G. E. 2002. Taxonomy and herbaria in service of plant conservation: lessons from Madagascar's endemic families. Annals of the Missouri Botanical Garden 89: 145-152.

Schmidt-Lebuhn, A. N., N. J. Knerr \& M. Kessler. 2013. Non-geographic collecting biases in herbarium specimens of Australian daisies (Asteraceae). Biodiversity and Conservation 22: 905-919.

Seregin, A. P. 2016. Making the Russian flora visible: fast digitisation of the Moscow University herbarium (MW) in 2015. Taxon 65: 203-209.

Smith, V. S. \& V. Blagoderov. 2012. Bringing collections out of the dark. ZooKeys 209: 1-6.

Stehlik, I., J. P. Caspersen, L. Wirth \& R. Holderegger. 2007. Floral free fall in the Swiss lowlands: Environmental determinants of local plant extinction in a peri-urban landscape. Journal of Ecology 95: 734-744.

Stropp, J., R. J. Ladle, A. C. M. Malhado, J. Hortal, J. Gaffuri, W. H. Temperley, J. O. Skøien \& P. Mayaux. 2016. Mapping ignorance: 300 years of knowledge of flowering plants in Africa. Global Ecology and Biogeography 25: $1085-1096$.

Suarez, A. V. \& N. D. Tsutsui. 2004. The value of museum collections for research and society. BioScience 54: 66-74.

Tang, C. Q., Y-F. Dong, S. Herrando-Moraira, T. Matsui, H. Ohashi, L.-Y. He, K. Nakao, N. Tanaka, M. Tomita, X.-S. Li, H.-Z. Yan, M.-C. Peng, J. Hu, R.-H. Yang, W.-J. Li, K. Yan, X. Hou, Z.-Y. Zhang \& J. López-Pujol. 2017. Potential effects of climate change on geographic distribution of the Tertiary relict tree species Davidia involucrata in China. Scientific Reports 7: 43822.

Taylor, J. W. \& Swann, E. C. 1994. DNA from herbarium specimens. Pp. 167-181. In: Herrmann, B. \& Hummel, S. (eds.), Ancient DNA. Springer, Berlin.

Tererai, F. \& A. R. Wood. 2014. On the present and potential distribution of Ageratina adenophora (Asteraceae) in South Africa. South African Journal of Botany 95: 152-158.

Thiers, B. 2016. Index Herbariorum: A global directory of public herbaria and associated staff. New York Botanical Garden's Virtual Herbarium. Available online: http://sweetgum.nybg.org/science/ih/ (accessed Aug. 31, 2016).

Vilà, M. \& I. Ibáñez. 2011. Plant invasions in the landscape. Landscape Ecology 26: 461-472.

Vroh, B. T. A., C. Y. A. Yao, K. B. Kpangui, Z. B. G. Bi, D. Kouamé, K. J. Koffi, B. J. C. Koffi \& K. E. N'Guessan. 2016. Comparing suitable habitat models to predict rare and endemic plant species distributions: what are the limits of the niche of Cola lorougnonis (Malvaceae) in Cote d'Ivoire? Environment and Natural Resources Research 6(3): 1-17.

Wang, Z. Q., D. Guillot, M. X. Ren \& J. López-Pujol. 2016a. Kalanchoe (Crassulaceae) as invasive aliens in China new records, and actual and potential distribution. Nordic Journal of Botany 34: 349-354.

Wang, C.-J., J.-Z. Wan, Z.-X. Zhang \& G.-M. Zhang. 2016b. Identifying appropriate protected areas for endangered fern species under climate change. SpringerPlus 5: 904.

Wen, J., S. M. Ickert-Bond, M. S. Appelhans, L. J. Dorr \& V. A. Funk. 2015. Collections-based systematics: Opportunities and outlook for 2050. Journal of Systematics and Evolution 53: 477-488.

Williams, J. N., C. Seo, J. Thorne, J. K. Nelson, S. Erwin, J. M. O’Brien \& M. W. Schwartz. 2009. Using species distribution models to predict new occurrences for rare plants. Diversity and Distributions 15: 565-576.

Winter, M. V. Devictor \& O. Schweiger. 2013. Phylogenetic diversity and nature conservation: where are we? Trends in Ecology and Evolution 28: 199-204.

Wolf, A., N. B. Zimmerman, W. R. L. Anderegg, P. E. Busby \& J. Christensen. 2016. Altitudinal shifts of the native and introduced flora of California in the context of 20th-century warming. Global Ecology and Biogeography 25: $418-429$.

Yang, W., K. Ma \& H. Kreft. 2013. Geographical sampling bias in a large distributional database and its effects on species richness-environment models. Journal of Biogeography 40: 1415-1426.

$\longrightarrow$ - - 2014. Environmental and socio-economic factors shaping the geography of floristic collections in China. Global Ecology and Biogeography 23: 1284-1292.

Zedane, L., C. Hong-Wa, J. Murienne, C. Jeziorski, B. G. Baldwin \& G. Besnard. 2016. Museomics illuminate the history of an extinct, paleoendemic plant lineage (Hesperelaea, Oleaceae) known from an 1875 collection from Guadalupe Island, Mexico. Biological Journal of the Linnean Society 117: 44-57.

Zhang, Z., J. S. He, J. Li \& Z. Tang. 2015. Distribution and conservation of threatened plants in China. Biological Conservation 192: 454-460.

Zhang, M.-G., J. W. F. Slik \& K.-P. Ma. 2016. Priority areas for the conservation of perennial plants in China. Biological Conservation (in press). 


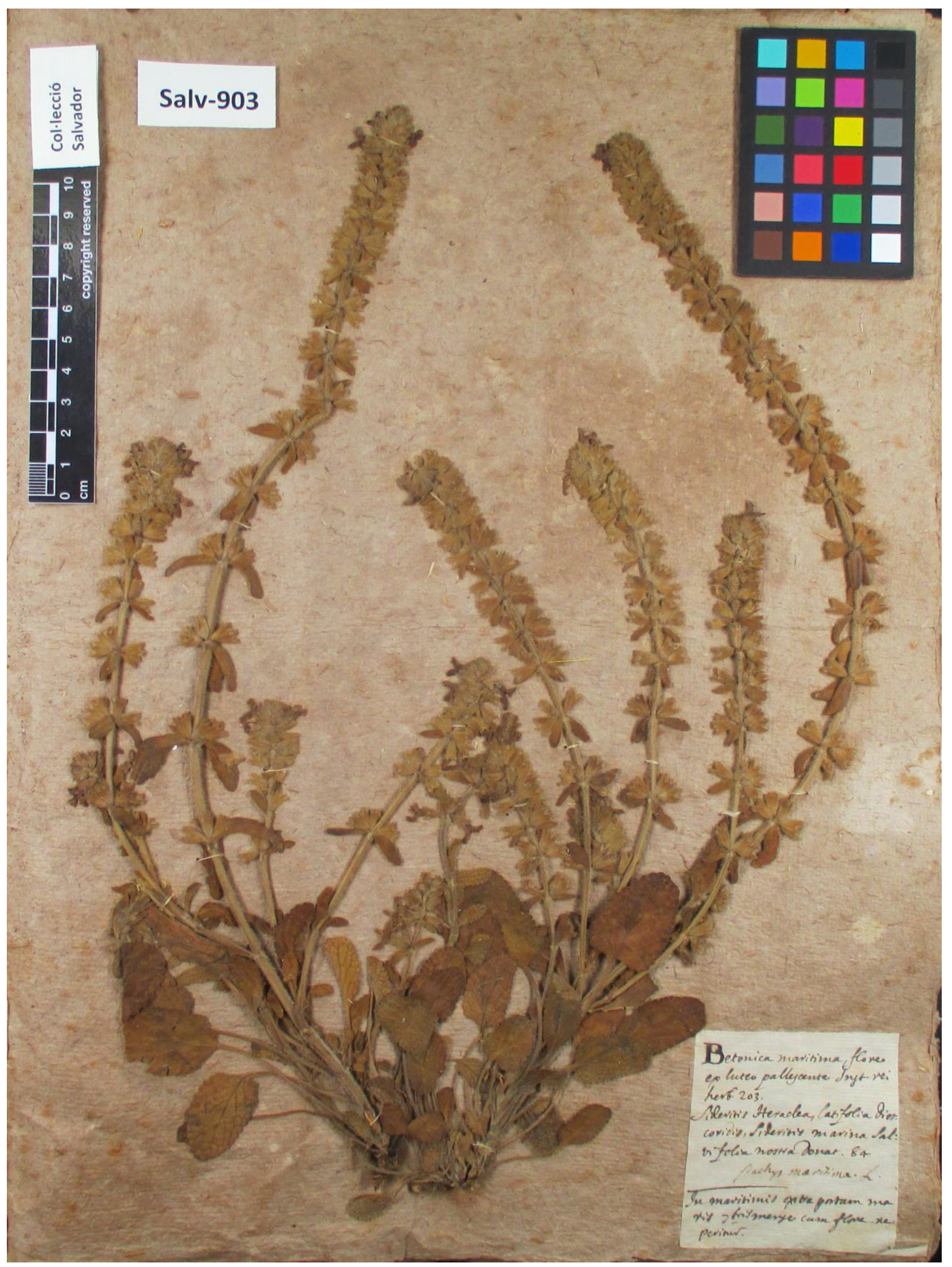

Fig. 1 Specimen of Stachys maritima Gouan from Portal del Mar, Barcelona, 18th century (BC-Salv-903), testimony of its presence in Barcelona's littoral, where it has disappeared 


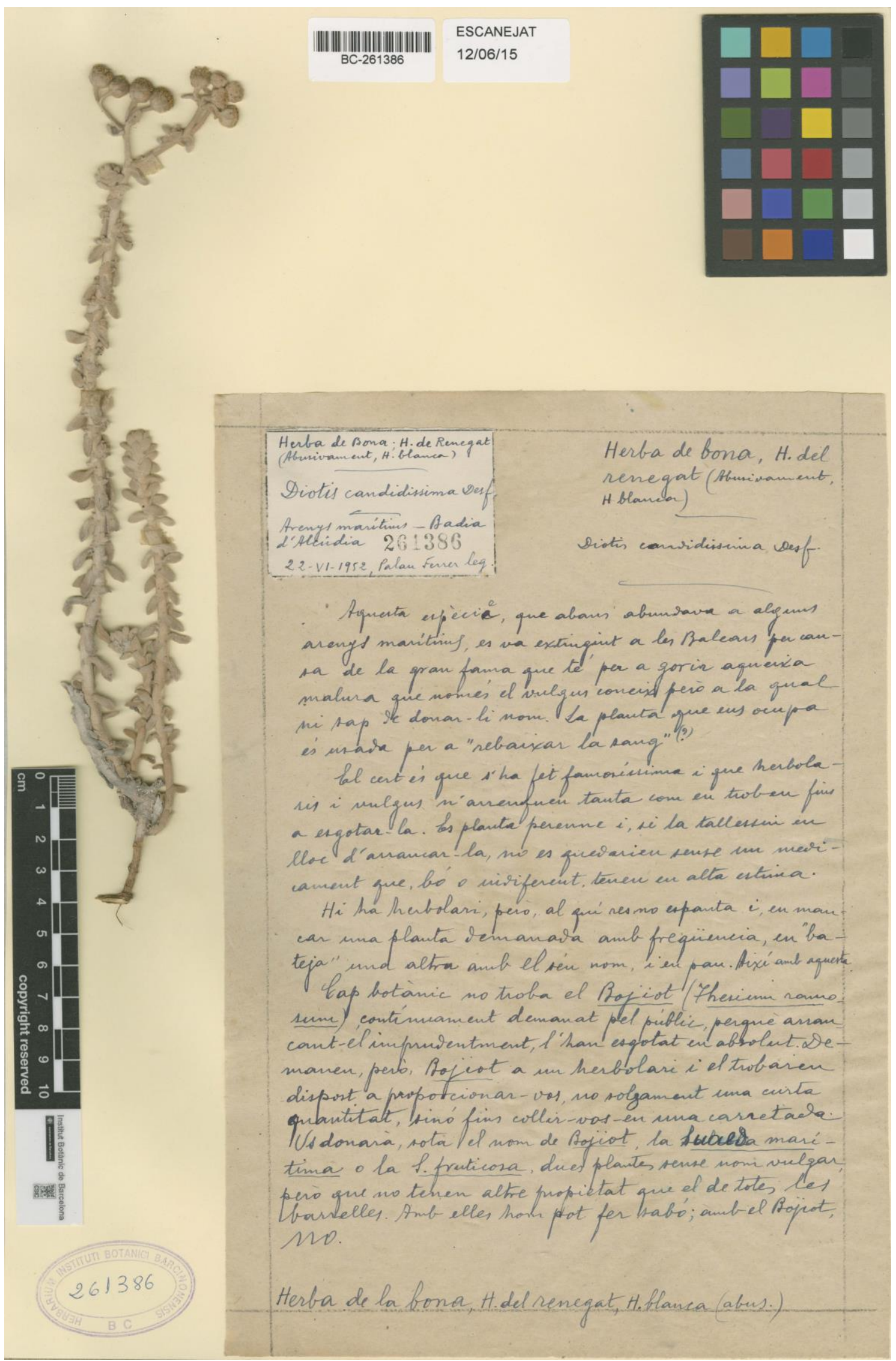

Fig. 2 Specimen of Achillea maritima from Badia d'Alcúdia, Mallorca, Balearic Islands, 22 June 1952 (BC-261386) with an annotation of its over-collection due its use as a medicinal plant 